\title{
REPORT OF THE WORKING PARTY ON NON-CONSULTANT (NON-TRAINING) GRADES IN PSYGHIATRY
}

The Working Party was set up to consider and review all the aspects of the non-consultant (nontraining) grades in psychiatry, including their terms and conditions of service, and make recommendations to the Manpower Sub-Committee. The present Report has been approved by Council as a basis for discussion.

The constitution of the Working Party was as follows: Members: Dr Felix Post (Chairman). Dr John Cobb (Manpower Sub-Committee and Working Party of Trainees), Dr Sally Pidd (Working Party of Trainees), Dr Edna Walker (Working Party on Women in Psychiatry); Advisers: Dr R. Arthur (Manpower Sub-Committee and BMA), Dr John Brothwood (DHSS), Dr Rodney Wilkins (Manpower Sub-Committee and DHSS).

Present Status in the Hospital Service

The present hospital career structure was agreed between the DHSS and the medical profession in a series of discussions in the late 1960 . The conclusions were summarized in the Second Progress Report (BMJ Supp, 1971.3.119). The critical decisions were: that consultant was to be the only career grade in the hospital service, that all junior posts were to be regarded primarily as training posts for future consultants, and that there should be no subconsultant grade. Medical assistant posts were to be established only in individual cases of doctors unable to compete for consultant status for personal reasons and were to lapse when the holder left. A Third Progress Report on the hospital staffing structure was agreed in 1972 (BMJ Supp, 1972, p. 143); this set out arrangements for senior registrars temporarily unable to obtain consultant posts, a final review of the status of S.H.M.O.s, the future of the Medical Assistant grade, and the agreement in principle to the establishment of a hospital practitioner grade.

Non-consultant, Non-training Grades in Psychiatric Specialties

1. Numbers in post at 30.9.75: England + Wales

\begin{tabular}{|c|c|c|c|c|c|c|c|c|c|c|c|}
\hline \multirow{2}{*}{\multicolumn{2}{|c|}{ Grade }} & \multicolumn{2}{|c|}{$\begin{array}{c}\text { Mental } \\
\text { Handicap }\end{array}$} & \multicolumn{2}{|c|}{$\begin{array}{l}\text { Mental } \\
\text { Illness }\end{array}$} & \multicolumn{2}{|c|}{$\begin{array}{l}\text { Mental } \\
\text { Illness } \\
\text { Children }\end{array}$} & \multicolumn{2}{|c|}{$\begin{array}{c}\text { Forensic } \\
\text { Psychiatry }\end{array}$} & \multicolumn{2}{|c|}{$\begin{array}{l}\text { Psycho- } \\
\text { therapy* }\end{array}$} \\
\hline & & No. & wte & No. & wte & No. & wte & No. & wte & No. & whe \\
\hline $\begin{array}{l}\text { S.H.M.O. with } \\
\text { allowance } \quad \text {. }\end{array}$ & . & $\mathbf{I}$ & $I \cdot O$ & 2 & $I \cdot O$ & $\mathbf{o}$ & & $\mathbf{o}$ & & o & \\
\hline $\begin{array}{l}\text { S.H.M.O. without } \\
\text { allowance } \quad . \\
\text { Medical Assistant }\end{array}$ & $\begin{array}{l}\cdots \\
\ldots\end{array}$ & $\begin{array}{r}4 \\
26\end{array}$ & $\begin{array}{r}4 \cdot 0 \\
24 \cdot 0\end{array}$ & $\begin{array}{r}37 \\
244\end{array}$ & $\begin{array}{r}35 \cdot 2 \\
222 \cdot 8\end{array}$ & $\begin{array}{l}\text { I } \\
9\end{array}$ & $\begin{array}{l}0 \cdot 2 \\
6 \cdot 9\end{array}$ & $\begin{array}{l}\mathbf{0} \\
\mathbf{0}\end{array}$ & & $\begin{array}{l}1 \\
4\end{array}$ & $\begin{array}{l}0 \cdot 5 \\
2 \cdot 7\end{array}$ \\
\hline $\begin{array}{l}\text { Part-time Medical } \\
\text { Officer (Clinical } \\
\text { Assistant) . . }\end{array}$ & $\ldots$ & 136 & $47 \cdot 8$ & 677 & $222 \cdot 9$ & 43 & 13.9 & o & & $\mathbf{I}$ & 0.2 \\
\hline Hospital Practitioner & & 0 & & 0 & & $\mathbf{o}$ & & $\mathbf{o}$ & & $\mathbf{o}$ & \\
\hline Other & .. & 1 & $I \cdot O$ & 2 & 0.6 & $\mathbf{I}$ & 0.2 & o & & $\mathbf{I}$ & $I \cdot 0$ \\
\hline [Consultant .. & .. & 137 & $135 \cdot 2$ & 994 & $899 \cdot 0$ & 221 & $19 I \cdot 3$ & 9 & & 10 & $6 \cdot 0]$ \\
\hline
\end{tabular}

Note: $w$ te $=$ whole-time equivalent.

- Figures recorded (National Statistical Tables) before DHSS differentiated psychotherapy posts. The majority of these therefore are included under 'Mental Illness'.

\section{Criteria for entry to grade}

S.H.M.O. Entry to this grade was closed in 1964.

Medical Three years post-registration hospital assistant experience, including two at registrar level (or equivalent) (para 11 of Hospital T \& G). In practice a higher qualification is expected, and the applicant should have expressed a wish for a personal grading of medical assistant. 
Clinical assistant (para 94 Hospital T \& C) no entry Hospital practitioner requirements.

Entrants must be principals in general practice and have been fully registered for four years. In addition, entrants should have two years fulltime or equivalent part-time experience of the specialty, or a higher qualification in the specialty (or equivalent) (para 6 of HSG(IS) 1 79).

\section{Terms and Conditions of Service}

Hospital These are set out in the circular practitioner HSG(IS) 179 .

All other These are covered by the Terms and grades Conditions of Hospital Medical Staff, 1971 , and its updatings.

4. This is a simplified statement of a complex matter which has local and ad hoc variations. The main point to note is that, compared with hospital practitioners and medical assistants, clinical assistants have no security of tenure and have a lower rate of pay which is also non-incremental regardless of experience and qualifications. We believe a number of doctors have remained in the clinical assistant grade too long because they have experienced difficulty in transferring to the medical assistant grade. It should also be noted that by 30 September 1975 there were no hospital practitioners working in psychiatry.

\section{1) Background}

\section{Recommendations}

It has been pointed out repeatedly that it is rational to have large numbers of doctors in grades designated as for training, only as long as there are sufficient consultant posts to offer trainees a future. Some authorities suggest that if there were only sufficient training posts to fill consultant posts falling vacant through death or retirement, there would be in the hospital service on an average, one registrar or senior registrar for every three consultants. On the other hand, it is widely agreed that psychiatric patients suffer from a lack of adequate medical staffing, not only as far as the attention to physical health which has to be given to long-term psychiatric patients of all ages but in regard to the increasing number of patients who have had active in-patient or out-patient treatment and are then discharged. Very many present long-term problems, and they, their families and their social and other supporting workers should be given assistance and advice by doctors with psychiatric skills. In psychiatry non- consultant doctors might take on a special responsibility for the management of such patients under the supervision of a consultant psychiatrist. They would develop expertise particularly in rehabilitation and supportive long-term care, but they would be expected to obtain consultant advice when in diffculties. They would be recruited from those who for domestic or other reasons had chosen not to take on the commitments of a consultantship in psychiatry.

\section{(2) Suggestions for the future}

(a) Our notice has been drawn to a resolution passed by the Central Committee for Hospital Medical Services (CGHMS) and endorsed by the General Medical Services Committee. This resolution extends the grade of hospital practitioner to doctors who are not principals in general practice, and reads as follows, referring to candidates for the grade:

(1) has reached a specified basic level of postgraduate training in the appropriate specialty,

(2) does not wish to progress towards a consultant appointment with its associated responsibilities, and

(3) wishes to work five sessions or less in NHS hospital practice.

If this new grade of hospital practitioner (non-GP) were to come into being there should not in our view be any rigid five-session limit. While such a limit will obviously be appropriate for doctors working primarily in general practice, it would be pointlessly restrictive for doctors who for a variety of reasons wish to work in psychiatry without formal training or consultant commitments. We recommend that nonGP hospital practitioners should be allowed to work a maximum of nine sessions a week-as for the clinical assistant grade.

(b) Failing the extension of the hospital practitioner grade to non-GPs we recommend the wider use of the medical assistant grade for the special needs of psychiatry. This would be open to doctors with appropriate qualifications and experience who again for a variety of reasons did not wish to assume consultant responsibility. We also suggest that the grade might perhaps be renamed 'Psychiatric Practitioner' grade and that as similar responsibilities are involved it should enjoy parity with the hospital practitioner grade. This proposal would not interfere in any way with the already established hospital practitioner grade nor with the appropriate use of the clinical assistant grade.

(c) Appointments to either the hospital practitioner (non-GP) or the psychiatric practitioner/medical 
assistant grade should be through Advisory Appointments Committees, which should include independent assessors to ensure that qualifications and experience are of an appropriate standard. In addition, the terms and conditions of service of these grades should be flexible and allow opportunities to apply for senior registrar and consultant posts, with credit for time of service in the 'non-training' grade where applicable.

(d) The clinical assistant grade should continue to be used to meet service needs, when a doctor has no specialist qualification to be graded otherwise, or when the work does not require specialist skills (e.g., the physical care of long-term patients).

The clinical assistant grade might also be retained for GPs who are desirous of increasing their experience in the specialty for use in general practice, or with a view to advancing at a later stage to the grade of hospital practitioner.

However, in the event of failure of the above recommendations, the Working Party would wish to reconsider the position of the clinical assistant grade.

\section{HENRY DIGKS}

The death on 12 July of Dr Henry Dicks, for many years Consultant at the Tavistock Clinic and a PastPresident of the Royal Medico-Psychological Association, removes one of the most outstanding and most admired figures of British psychiatry. He was born in Pernau, Estonia (then Russia) in 1900. His father was an English exporter and ship owner who also acted as British Vice-Consul, and his mother came from a cultured academic German family. The family returned to England after the upheavals of the first World War and the Russian Revolution, but by then Henry had had a considerable classical education in Leningrad. Speaking English, Russian and German like a native, and with good French, he became an interpreter with Military Intelligence in North Russia with the British Expeditionary Force and subsequently with the British Military Mission to General Denikin in South Russia and the Caucasus.

While at school, Henry had at times contemplated music as a profession-he remained a keen violinist all his life, playing in several chamber groups and in recent years the London Medical Orchestra-but on leaving the army he decided to study medicine. At St. John's College, Cambridge and then Bart's he was an outstanding student gaining several academic prizes and distinctions. Qualifying in 1926 he went on to take his M.R.C.P. in $19^{27}$ and his M.D. in 1930, by which time he had become Chief Assistant to Lord Horder. From such prospects it was a courageous step to join the relatively new Tavistock Clinic. Doubtless his cultured cosmopolitan background contributed to this early interest in psychological medicine, for his profoundly humanistic concern perpetually directed his interests to the study of the whole man in his particular culture. This wide perspective was also the important factor in his decision to train at the Tavistock rather than with the psychoanalysts.
His talents for his new field of study were quickly manifested, for within a few years he was Assistant Medical Director. From further experience he published in 1939 his Clinical Studies in Psychopathology. This was a popular textbook and it is of interest today to note that Dicks was then articulately alive to the constrictive materialistic philosophy in medicine, especially in neurology. Within his more comprehensive philosophy of the nature of man, he offered as a sheet anchor to those confronting the complexities of psychopathology the view that 'every patient with mental illness was more afraid than he could tolerate when he was a baby, and the faults in his psychic structure represent the gallant attempts to allay this intolerable feeling by the inadequate means at his disposal'. The prescience of this generalization is an excellent indicator of the extent to which all of his work evolved from a wisdom that contrasts notably with the limitations of more doctrinaire attitudes.

When World War II broke out, Dicks went with some of his colleagues to the EMS Neurosis Centre at Stanborough, Watford, and in 194 $I$ he joined the Army as a Specialist Psychiatrist, being Command Psychiatrist, London District for a time. But the landing in this country of Rudolf Hess soon started him on a new line of work. With his unusual facility in German, he was sent to be in medical care of this highly important prisoner, an experience which he subsequently described in The Case of Rudolf Hess. During the next four years, with the rank of Lt. Col., he was adviser with the Army on German morale, with SHAEF on psychological warfare, and with the Control Commission on German personnel. This work subsequently led to his collaboration with many distinguished anthropologists in Europe and the United States in projects on Culture and Personality carried out for UNESCO. In more recent years he was a Senior Research Officer at the Columbus 